\title{
Ideology and Public Support for the Supreme Court
}

\author{
Kathryn Haglin* \\ Soren Jordan ${ }^{\dagger}$ \\ Alison Higgins Merrill ${ }^{\ddagger}$ \\ Joseph Daniel Ura ${ }^{\S}$
}

October 19, 2018

\begin{abstract}
An extensive literature spanning political science, law, and other fields recognizes that public support for judicial authority insulates courts from political pressures and catalyzes compliance with judicial decisions. The nexus between public sentiment and judicial power is especially salient for the Supreme Court of the United States, whose unelected members exercise judicial review of federal and state laws and executive actions. Yet, a variety of data indicate declining public support for the United States Supreme Court over the last decade or more. Here, we develop and assess an account of ideological asymmetries in public support for the Supreme Court. We find that specific support for the Supreme Court is more strongly negatively related to perceptions that the Court is overly liberal than perceptions that the Court is overly conservative.
\end{abstract}

*Post-Doctoral Research Fellow, Annenberg School for Communication, University of Pennsylvania

$\dagger$ Assistant Professor, Department of Political Science, Auburn University

$\ddagger$ Assistant Professor, Department of Political Science, Susquehanna University

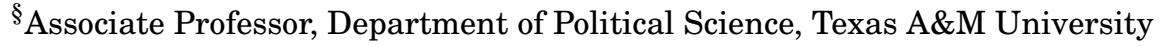




\section{Introduction}

Americans' evaluations of the Supreme Court's job performance have declined over the last decade (Sinozich, 2017; Merrill, Conway, and Ura, 2017; Ura and Merrill, 2017). While diffuse support for the Court remains high and stable (Enns and Wohlfarth, 2017; Gibson and Caldeira, 2009; Gibson and Nelson, 2014), a variety of academic and commercial surveys show that Americans express much less approval of and confidence in the Supreme Court than they did in the early 2000s (e.g. Jones 2016, Pew Research Center 2015; Merrill and Ura 2017; Sinozich 2017, but see Brenan 2018 on a recent uptick in Supreme Court approval). Although scholars have typically argued that political support for is anchored in diffuse support for the Supreme Court, a growing body of empirical evidence shows lower specific support for the Supreme Court threatens judicial independence and encourages congressional court curbing (Armaly, 2016; Clark, 2009; Friedman, 2009; Hall, 2011; Ura and Wohlfarth, 2010; Ura and Merrill, 2017). Likewise, persistently low performance approval eventually may erode legitimacy and threaten the Court's essential institutional integrity and constitutional standing (Gibson and Nelson, 2014; Kramer, 2004; Riker, 1980). The Supreme Court's decade-long slide in public approval is, therefore, evidence of a fissure in the foundations of judicial independence in the United States. Understanding the dynamic processes that enhance or erode public support for the Supreme Court is a critical problem for scholars of American national government.

The scholarly literature on the dynamics of aggregate specific support for the Supreme Court identifies two principal factors associated with attitudes about the Court's job performance (Ansolabehere and White 2018; Durr, Martin, and Wolbrecht 2000; Malhotra and Jessee 2014; Sinozich 2017; see also Caldeira 1986, 1987, 1991, Mondak 1992, Mondak and Grosskopf 1997). The first is dispositions toward the federal government as a whole, especially attitudes toward Congress (Durr, Martin, and Wolbrecht 2000; Sinozich 2017). Evaluations of the Supreme Court's performance rise and fall with evaluations of the federal government as a whole. The second is the degree of ideological divergence between 
Supreme Court decision-making and public mood (Durr, Martin, and Wolbrecht 2000). As the ideological tenor of aggregate Supreme Court decision-making diverges from the public's medially preferred level of policy liberalism, total support for the Supreme Court declines.

Research on the nature of Americans' ideological and partisan commitments, though, suggests that the second prong of this account may be incomplete. American political conservatism is tied to a relatively simple value space centered on a commitment to "individualism," which often manifests as support for personal liberty and laissez-faire economic principles (Franklin and Jackson, 1983; Feldman and Zaller, 1992; Goren, 2001; McClosky and Zaller, 1984). Political liberalism in the United States is associated with a relatively complex value space that includes both individualism and "egalitarianism," which is evident in support for policies promoting social and economic equality (Franklin and Jackson, 1983; Feldman and Zaller, 1992; Goren, 2001). These differences in ideological value structures are reinforced by the nation's leading political parties. The Republican Party is organized around a shared set of ideological commitments while the Democratic Party is organized as a coalition of diverse interests (Grossman 2016; see also Converse, Clausen, and Miller 1965; Goggin and Theodoridis 2017, 2018, McClosky, Hoffmann, and O’Hara 1960).

One consequence of these differences in ideological values commitments and concomitant party structures is that conservatives may experience more intense responses to some political stimuli than liberals. In particular, liberals' disappointment in an inegalitarian policy outcomes may be offset by their satisfaction with its individualist effects while conservatives find no such silver lining in equality-enhancing policies. So, for example, Republicans' policy mood responds more strongly to changes in domestic spending than Democrats' policy mood (Ura and Ellis, 2012). These same dynamics point to a model of ideological asymmetry in aggregate evaluations of the Supreme Court's performance: specific support for the Supreme Court should be more strongly related to perceptions that the Court is overly liberal than perception that the Court is overly conservative.

This paper develops and assesses this and related theoretical claims. We proceed 
by briefly reviewing the literatures on the dynamics of aggregate specific support for the Supreme Court and ideological value structures. Next, we synthesize these two bodies of research and propose a theory of asymmetrical consequences in public support for the Supreme Court for judicial deviation from the public's medial ideological position. We assess these theoretical claims using Gallup data on Americans' approval for the Supreme Court and their perceptions of whether the Supreme Court's decisions are "too liberal, too conservative, or about right." The data support our hypotheses about ideological asymmetries in evaluations of the Supreme Court. Our analysis shows that aggregate Supreme Court approval is more strongly associated with changes in the proportion of Americans who view the Court as too liberal than changes in the proportion of respondents who view the Court as too conservative.

These results have several important implications. First, our findings provide support for a more complete theoretical account of dynamics in public support for the Supreme Court and, in particular, suggest a mechanism behind the recent decline in the Supreme Court's public standing. Our findings also point toward dynamics in public opinion that create strategic incentives for the Supreme Court and its justices to be especially attentive to the preferences of American conservatives. Finally, our findings also provide a framework for future research on the ideological and partisan cleavages that emerge around the Supreme Court and its controversial decisions.

\section{Public Support for the Supreme Court}

For half a century, political scientists have recognized two classes of attitudes about institutions in general, and about constitutional courts, in particular: diffuse support and specific support (Easton 1965; see also Gibson and Caldeira 2009; Gibson and Nelson 2018). Diffuse support refers to "reservoir of favorable attitudes or goodwill that helps members to accept or tolerate outputs to which they are opposed or the effects of which they see as damaging to 
their wants" (Easton 1965, p. 273). Diffuse support for an institution indicates a willingness to accept and abide by its decisions, even when those decisions are inconsistent with one's preferences or interests. Gibson (2012) equates diffuse support with "legitimacy" and "loyalty." Similarly, Gibson, Caldeira, and Spence (2003a) associate diffuse support with "trust" and "accept[ance]" and suggest that diffuse support is best measured by assessing survey respondents' willingness to limit or eliminate the Supreme Court's institutional authority.

Conversely, specific support refers to "the favorable attitudes and predisposition stimulated by outputs that are perceived by [individuals] to meet their demands as they arise or in anticipation" (Easton 1965, p. 273). Specific support is the belief that an institution produces outcomes consistent with one's preferences or interests. Gibson (2012) refers to specific support as "performance satisfaction." Gibson, Caldeira, and Spence (2003a) associate specific support with "approval" and "confidence."

Scholars have argued that political support for an independent Supreme Court and people's willingness to comply with disagreeable judicial decisions are anchored in diffuse support for the Supreme Court. For example, Gibson, Caldeira, and Spence (2003a) contend that:

the most important attitudes ordinary citizens hold toward institutions like the Supreme Court have to do with institutional loyalty. Institutions like courts need the leeway to be able to go against public opinion (as for instance in protecting unpopular political minorities). Thus, a crucial attribute of judicial institutions is the degree to which they enjoy the loyalty of their constituents (p. $356)$.

Although institutional loyalty is undoubtedly a deeply consequential dimension of public evaluations of the Supreme Court, recent research demonstrates specific support for the Court has important implications for its willingness to act independently.

A growing body of empirical evidence shows lower specific support for the Supreme Court threatens judicial independence and encourages congressional court curbing (Armaly, 
2016; Clark, 2009; Ura and Wohlfarth, 2010; Merrill, Conway, and Ura, 2017). Likewise, persistently low performance approval may eventually erode legitimacy and threaten the Court's essential institutional integrity and constitutional standing (Gibson, Caldeira, and Spence, 2003b; Kramer, 2004; Riker, 1980). The Supreme Court's decline in public approval is, therefore, evidence of a serious fault in the foundations of judicial independence in the United States.

\section{Accounting for SUpport}

Prior studies of on the dynamics of specific support for the Supreme Court identifies two principal factors associated with the changes in the public's view of the Supreme Court's performance (Durr, Martin, and Wolbrecht 2000; Hitt and Searles 2018; Sinozich 2017; see also Caldeira 1986, 1987, 1991, Mondak 1992, Mondak and Grosskopf 1997, Ura and Merill 2017). The first is the public's disposition toward the federal government as a whole, especially attitudes toward Congress. There is convincing evidence that aggregate trust in government is an important, latent dimension of Americans' evaluations of the state as a whole that influences views of individual governing institutions (Hetherington, 1998, 2005; Keele, 2007). The public's evaluation of the Supreme Court's performance therefore rises and falls with its evaluations of the federal government as a whole (Durr, Martin, and Wolbrecht 2000; Sinozich 2017). In other words:

The Congressional Support Hypothesis: Specific support for the Supreme Court is positively related to specific support for Congress.

The second is the degree of ideological divergence between Supreme Court decisionmaking and public mood. ${ }^{1}$ Scholars have argued that "the Court's support relies in part

\footnotetext{
${ }^{1}$ Policy "mood" indicates Americans' "changing general disposition" toward a "latent [liberal-conservative] continuum underlying expressed policy preferences” (Stimson 1999: 20-31). Mood represents the nation's level of demand for greater or less liberalism in domestic public policy (Stimson, Erikson, and MacKuen 1995: 544; see also Erikson, Stimson, and MacKuen 2002; Ellis, Ura, and Robinson 2006; Kellstedt, Peterson, and Ramirez 2010; Smith 2000; Stimson 2004; Ura 2014), which is essentially the first principal component of
} 
on the degree to which the public agrees or disagrees with its decisions" (Durr, Martin, and Wolbrecht 2000, p. 770; see also Ansolabehere and White 2018, Malhotra and Jessee 2014, Mondak and Grosskopf 1998; Mondak 1992). As the ideological tenor of aggregate Supreme Court decision-making diverges from the public's medially preferred level of policy liberalism, aggregate public support for the Supreme Court increases. We therefore expect:

The Ideological Divergence Hypothesis: Overall ideological dissatisfaction with Supreme Court decisions should be negatively related to specific support for the Supreme Court.

\section{Conceptualizing Ideological Divergence}

The American public is not a unitary actor. Americans' individual preferences for political outcomes are distributed across policy spaces, and their macro-level approval or disapproval of a policy decision, set of policy decisions, or policymaking institution is an aggregation of a range of individual attitudes. The macro-level concept of ideological divergence between the Supreme Court and public mood is, therefore, a mapping of the array of micro-level political responses to the Court's decisions to another level of analysis.

Stimson's (1999) canonical micro-level theory of public mood is a guide for unpacking overall ideological divergence between the Supreme Court and public sentiment to better understand its constituent parts. Stimson argues that specific public policies can be mapped into a liberal-conservative space that correspond to an important dimension of individuals' preferences for government action. Individuals have one of three reactions to the public policy. They will regard it as either too liberal, too conservative, or about right. Policies that are clearly more liberal or more conservative than an individual prefers will elicit his or her disapproval. Policies that are close enough to his or her preferred outcome will meet acceptance or "acquiescence" (p. 21). For policymakers, the set of policy alternatives that

shared longitudinal variance among dozens of time series of survey marginals from major polling organizations collected since the early 1950 s. 
are close enough to the preferences of an (undefined but presumably majoritarian) critical mass of citizens exist in a "zone of acquiescence," which is the plausible set of alternatives an election-minded politician might advocate under normal circumstances (Stimson 1999, pp. 20-26).

This theoretical model of attitudes toward policy is illustrated in the top panel of Figure $1 .^{2}$ The top panel shows a hypothetical distribution of individual policy preferences (ideal points) in a liberal-conservative policy space along with a moderate status quo policy. Individuals with relative. Individuals with especially liberal (left) policy preferences disapprove of the policy because it is too conservative for their tastes. Individuals with especially conservative (right) preferences disapprove of the policy because it is too liberal for their tastes. Individuals with relatively centrist preferences acquiesce to or approve of the policy because it is close enough to their preferred outcomes.

Suppose now that the current policy shown in the top panel shifted to the left. At the macro-level, there would be a decrease in overall support for the policy as it shifted away from the medially preferred outcome. However, there would be a range of microlevel responses and nonresponses to the change. The most extreme liberals would regard the new policy as still too conservative for their tastes and continue in their disapproval. More moderate liberals who had found the old policy too conservative would judge the new policy to be close enough to their preferred outcome to switch from disapproval to approval. Centrists whose tastes are subjectively "close enough" to both the old and new policies would continue to express approval. Moderate conservatives who had found the original policy acceptable would see the new policy as too far from their preferred outcomes and switch from expressing approval to disapproval. Finally, the most extreme conservatives would express disapproval of the new policy just as they had for the original policy.

The ideological divergence theory of aggregate specific support for the Supreme Court assumes this basic mechanism motivates evaluations of the Supreme Court. Individually,

\footnotetext{
${ }^{2}$ Figure adapted from Stimson (1999, p. 22).
} 

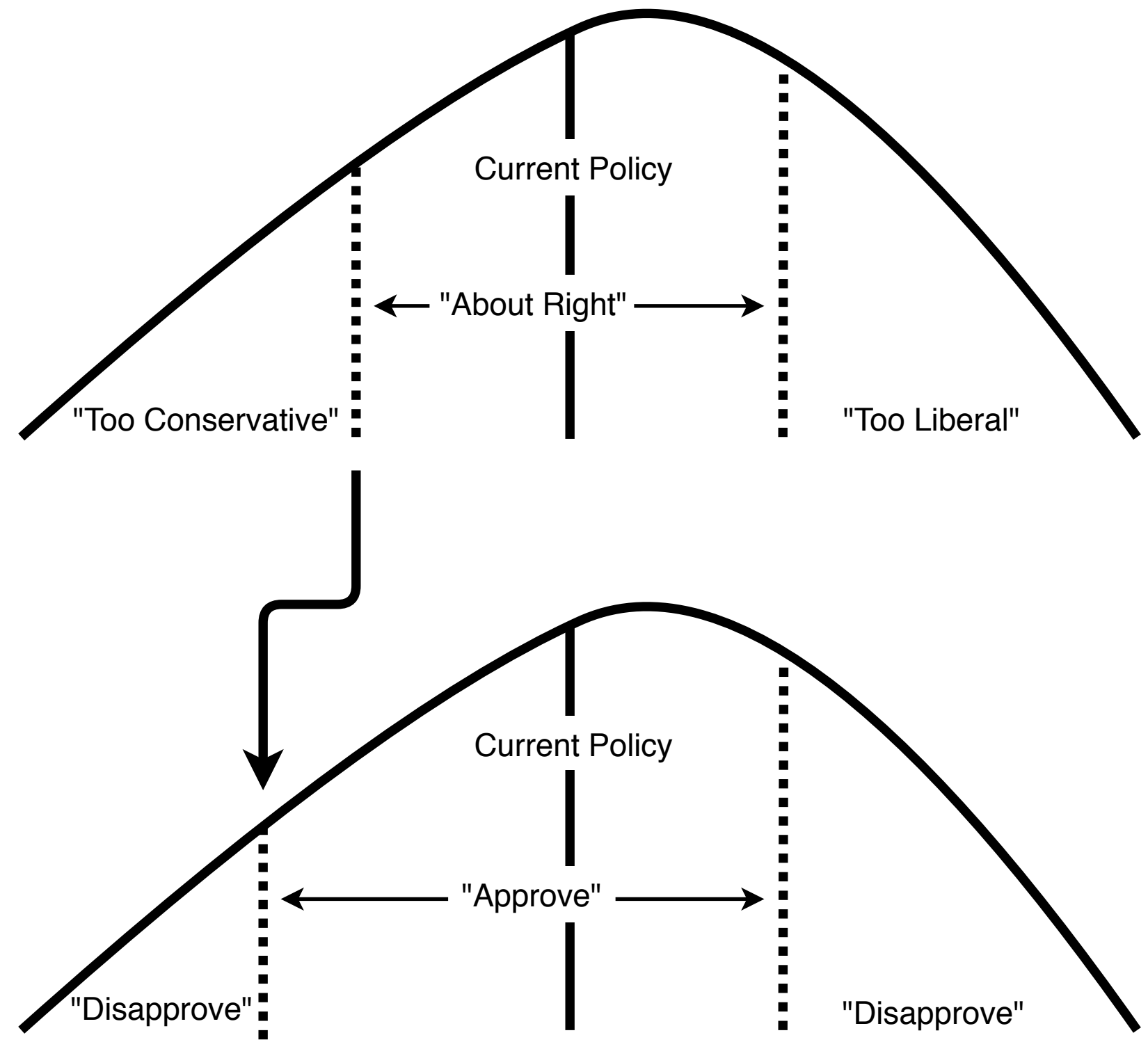

Figure 1: Aggregation of Policy Evaluations and Institutional Approval 
people will say they disapprove of the Supreme Court when the Supreme Court makes enough salient decisions that are far enough away from their preferred outcomes in those cases. In the aggregate, specific support for the Supreme Court will fall as its decisions increasingly deviate from the center of the distribution of preferences outcomes in its cases.

This mechanism incorporates at least three substantive assumptions. First, there is some relation between the Court's production of decisions that are generally close enough to an individual's ideological preferences and his or her propensity to say they support the Supreme Court in a survey. Second, ideological preferences over policies affected by Supreme Court decisions are roughly normally distributed, i.e. most dense in the middle of the distribution (at the level of liberalism indicated by the policy mood index in Durr, Martin, and Wolbrecht's [2000] empirical assessment of the ideological divergence hypothesis) with reasonably balanced tails. And third, the exchange function that translates acceptance of or disagreement with Supreme Court decisions into positive or negative evaluations of the Court's job performance is ideologically symmetrical so that excessive liberalism in the Court's decisions is just as consequential as excessive conservatism for public support for the Court.

The assumption about the arbitrage between policies' ideological divergence from individual preferences and support for a policymaking institution is cogent and consistent with research onresponses to changing public policy (e.g. Durr, 1993; Erikson, MacKuen, and Stimson, 2002; Wlezien, 1995; Ura, 2014; Wlezien, 1996). Likewise, the assumption about density in the zone acquiescence is consistent with evidence about the distribution of policy preferences in the mass public (Ellis and Stimson, 2012; Erikson, MacKuen, and Stimson, 2002; Nolan McCarty and Rosenthal, 2008; Page and Shapiro, 1982, 2010; Stimson, 1999). However, there are strong reasons to question the assumption of ideological symmetry in evaluations of the Supreme Court's job performance. 


\section{Ideological Asymmetry in Evaluations of the Supreme Court}

American political conservatism tied to a relatively simple value space centered on a commitment to "individualism," which often manifests as support for personal liberty and laissezfaire economic principles (Franklin and Jackson, 1983; Feldman and Zaller, 1992; Goren, 2001; McClosky and Zaller, 1984). Political liberalism in the United States is associated with a relatively complex value space that includes both individualism and "egalitarianism," which is evident in support for policies promoting social and economic equality (Franklin and Jackson, 1983; Feldman and Zaller, 1992; Goren, 2001). These differences in ideological value structures are amplified by the nation's leading political parties. The Republican Party is organized around a shared set of ideological commitments while the Democratic Party is organized as a coalition of diverse interests (Grossman 2016; see also Converse, Clausen, and Miller 1965; Goggin and Theodoridis 2017, 2018, McClosky, Hoffmann, and O’Hara 1960).

One consequence of the difference in ideological values commitments and concomitant party structures is that conservatives may experience more intense responses to some political stimuli than liberals. In particular, liberals' disappointment in an inegalitarian policy outcomes may be offset by their satisfaction with its individualist effects while conservatives find no such silver lining in equality-enhancing policies. So, for example, Republicans' policy mood responds more strongly to changes in domestic spending than Democrats' policy mood (Ura and Ellis, 2012).

Not all partisans are ideologues on either the left or right sides of American public (e.g. Converse, 1964; Ellis and Stimson, 2012). Yet, these imbalanced ideological values structures should have consequences for individuals' evaluations of policymaking institutions. In the aggregate, these differences should influence dynamics of specific support for the institutions of government, including the Supreme Court. 
In particular, left Americans' (liberals and Democrats) objections to policymaking, including Supreme Court decisions, should be less likely to influence their evaluations of the institution's overall job performance than right Americans' (conservatives and Republicans) objections, either because they are more ambivalent about unfavorable policy outcomes than Republicans or because unfavorable outcomes may affect the various parts of the Democratic Party's constituency in different ways in contrast to Republicans' more unified, ideological reactions. For example, suppose the Supreme Court's decisions shifted from being too liberal to too conservative for the median American. This change would lead some left Americans to experience less satisfaction with the Court's decisions. Conversely, some right Americans to would experience more satisfaction with the Court and express greater approval of the Court.

However, the ease with which the two groups translate those feelings into evaluations of the Supreme Court should be different. Left Americans' relative value complexity and less ideological partisan commitments should make it more difficult to translate their increased dissatisfaction with the Court's rulings into a less positive evaluation of the Court's performance. Right Americans' relative value simplicity and more ideological partisan commitments should create less fiction in the translation of their increased satisfaction with the Court's rulings into a more positive evaluation of the Court's performance.

Asymmetries ideologically motivated evaluations of the Supreme Court are illustrated in Figure 1. Again, the top panel shows a hypothetical distribution of individual policy preferences and policy judgments (too liberal, too conservative, or about right) in a liberalconservative policy space surrounding a status quo policy. The bottom panel shows the expected correspondence between individuals' evaluations of policy and their evaluations of a policymaking institution's job performance. Among conservatives, the correspondence between evaluations of policy and evaluations of policymaking institutions should be relatively seamless. Conservatives approve of an institution when the policies it makes are acceptable to them, and they disapprove of an institution when it makes policies that are 
unacceptable to them. Among liberals, evaluations of policy and evaluations of policymaking institutions are less synchronous. There should be a margin of liberals who find a policy or set of policies unacceptable without projecting that disapproval onto the responsible policymaking institution.

These anticipated dynamics point to a model of ideological asymmetry in aggregate evaluations of the Supreme Court's performance. Too much liberalism in Supreme Court decision-making should erode the public's aggregate approval or confidence in the Supreme Court to a greater degree than too much conservatism in the Court's decisions. We therefore hypothesize that:

The Asymmetrical Divergence Hypothesis: Total specific support for the Supreme Court is more strongly negatively related to perceptions that the Court is overly liberal than perceptions that the Court is overly conservative.

\section{Political Context, the Zone of Acquiescence, and Eval- uations of the Supreme Court}

Of course, the Supreme Court does not select or decide cases in a political vacuum, and Americans observe the Court in relation to other political actors and its decisions relative to other policymaking choices. Presidential partisanship substantially influences the ideological location of policymaking throughout the federal government (e.g. Bailey, Kamoie, and Maltzman, 2005; Chappell, Havrilesky, and McGregor, 1993; Edwards, 1976, 1980; Kriner and Reeves, 2015; Peake, 2001). A change in presidential partisanship should therefore accompany a change in the slice of Americans who view their government as ideologically out of line. Switching from a Democrat to a Republican in the White House should increase the proportion of right partisans and ideologues who find the government's actions acceptable and increase the proportion of left partisans and ideologues who view the government as too conservative. Conversely, a change from a Republican president to a Democratic president 
should increase the proportion of left partisans and ideologues who find the government's actions acceptable and increase the proportion of right partisans and ideologues who view the government as too liberal.

This presidential influence in Americans' views of the national government as a whole should reflect on the Supreme Court. First, the ideological tenor of Supreme Court decisions is substantially related to the partisanship of the presidency. Since 1953, the mean percentage of Supreme Court cases decided in a liberal direction per term is $52.4 \%$, according to the United States Supreme Court Database (2018). During Democratic administrations, an average of $57.9 \%$ of cases per term are decided in a liberal direction, and, during Republican administrations, an average of only $47.7 \%$ of cases per term are decided in a liberal direction. This difference is the cumulative result of changes in the Court's docket related to differences in presidential priorities (Perry, 1994; Merrill, 2018), the influence of the president's Solicitor General on the Court's decisions (Bailey, Kamoie, and Maltzman, 2005; Caplan, 1987), the Court's strategic deference to the elected branches of national government (Segal, Westerland, and Lindquist, 2011; Hall and Ura, 2015; Whittington, 2005), the effect of president's Supreme Court appointments (Dahl, 1957; Funston, 1975; Segal, Timpone, and Howard, 2000), and other factors. Also, more impressionisticly, Americans may reasonably see the Supreme Court as part of the "dominant national alliance," along with those in control of Congress and the executive branch (Dahl 1957, p. 293). To the extent that the president is a national policymaking leader, Americans may impute the politics of the president to the entire federal government, including the Supreme Court, even if they are unaware of specific presidential influence. We therefore expect,

The Presidential Projection Hypothesis: A greater proportion of Americans will say the Supreme Court is too liberal when a Democrat is president than when a Republican is president, and a greater proportion of Americans will say the Supreme Court is too conservative when a Republican is president than when a Democrat is president. 
We furthermore expect that the influence of presidential partisanship on evaluations of the Supreme Court interacts with the asymmetries in partisan and ideological values commitments and responses to political stimuli. Once again, we expect right ideologues and partisans to be more sensitive than left ideologues and partisans to changes in policy and the political environment and more readily translate their attitudes toward policy into evaluations of policymaking institutions. So, when the Supreme Court becomes more liberal during a Democratic administration, both in its actual decisions and symbolically as part of the national regime led by the president, conservatives and Republicans will express disapproval of the Supreme Court more readily than Democrats and progressives will as the Court becomes more conservative, actually and symbolically, during a Republican administration. We therefore hypothesize,

The Presidential Partisanship Hypothesis All else equal, specific support for the Supreme Court should be lower during a Democratic presidency than a Republican presidency.

\section{Empirical Analysis}

In order to test these claims, we proceed in three steps. First, we evaluate the expected links between presidential partisanship evaluations of the Supreme Court. Next, we conceptually replicate Martin, and Wolbrecht's (2000) basic modeling strategy with new data to reevaluate the ideological divergence and congressional support hypotheses. Finally, we extend this approach to test the asymmetrical divergence hypothesis.

\subsection{Measurement and Data}

In order to implement these tests, we we identify indicators of specific support for the Supreme Court, perceptions of the overall divergence between the ideological tenor of Supreme Court decisions and the public's preferred level of policy liberalism, indicators of the degree 
to which Supreme Court decision-making deviates from Americans' preferences in a liberal direction and in a conservative direction, specific support for Congress, and presidential partisanship.

The Gallup Organization has asked representative samples of American adults three poll questions together in the same surveys at least once a year since 2000 that directly correspond to these key public opinion variables, and, of course, the party of the president is easily identifiable. The first Gallup question asks respondents, "Do you approve or disapprove of the way the Supreme Court is handling its job?" This measures Americans' specific support for the Supreme Court. Of course, measures of specific support and diffuse support for the Supreme Court share much common cross-sectional variance Gibson, Caldeira, and Spence (2003a). However, Gallup's approval question is as nearly as possible a direct measure of individuals' specific support for the Court. We have no theoretically motivated interpretation of variance in the percentage of respondents who decline to answer the question or say they "don't know" or are "unsure" of the answer. We therefore exclude these responses, and rely on the percentages of respondents answering "approve" or "disapprove" among those who provide a definite response to the question to indicate the concepts of interest.

The second is, "In general, do you think the current Supreme Court is too liberal, too conservative, or just about right?" This questions provides evidence of both Americans' overall satisfaction with Supreme Court decision-making (the percentage saying the Court is "just about right") and indicates the direction of Americans' ideological disappointment with the the Court (the percentages saying "too liberal" or "too conservative"). Durrr, Martin, and Wolbrecht's (2000) study of public support for the Supreme Court relied on an indirect measure of ideological divergence between Supreme Court decisions and the public's preferences for policymaking. Their approach measured ideological divergence as the negative multiplicative interaction of the deviations of the percentage of salient Supreme Court decisions decided in a liberal direction and average value Stimson's $(1991,1999)$ mood index 


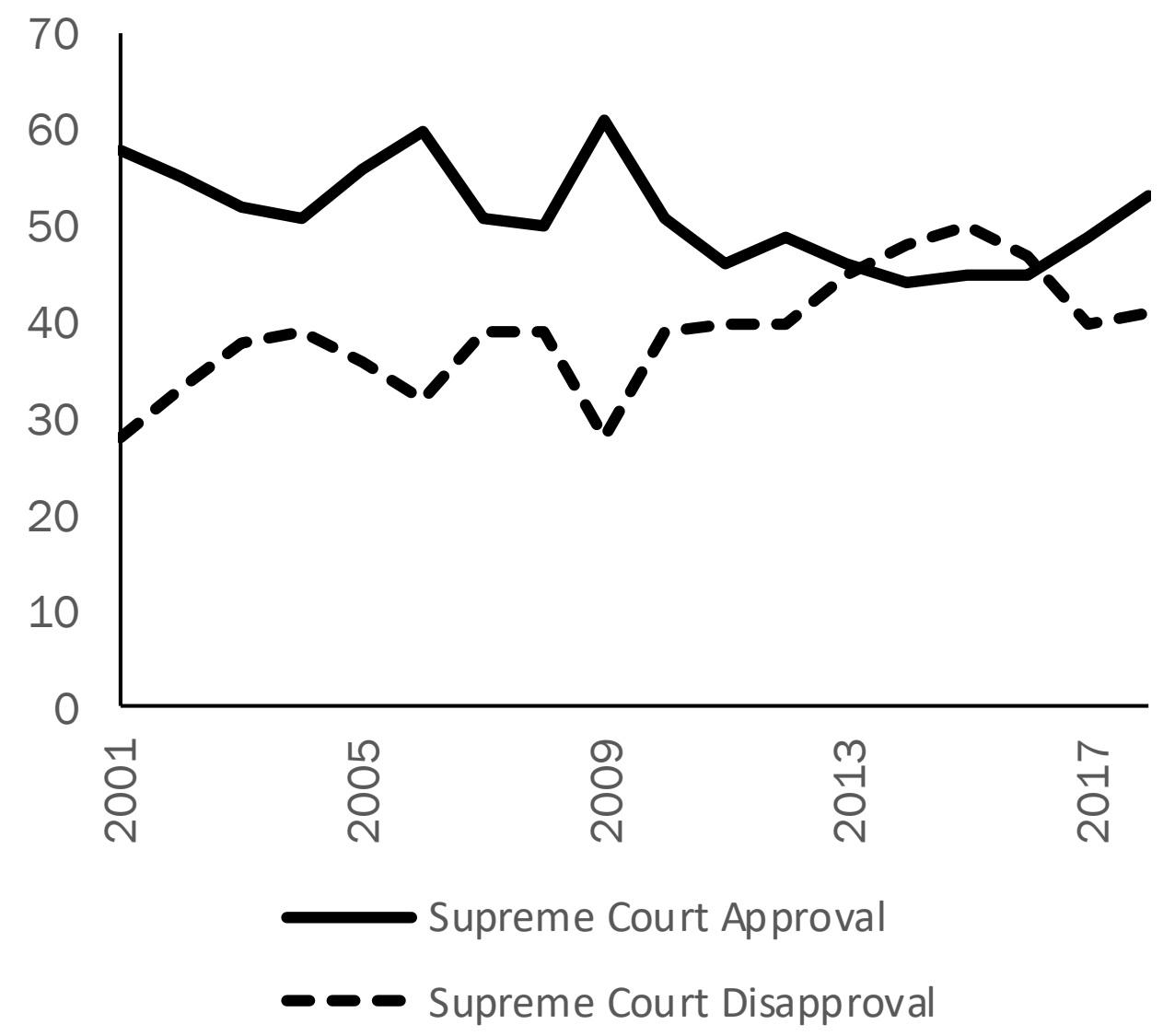

Figure 2: Annual Supreme Court Approval (Gallup), 2001-2018 


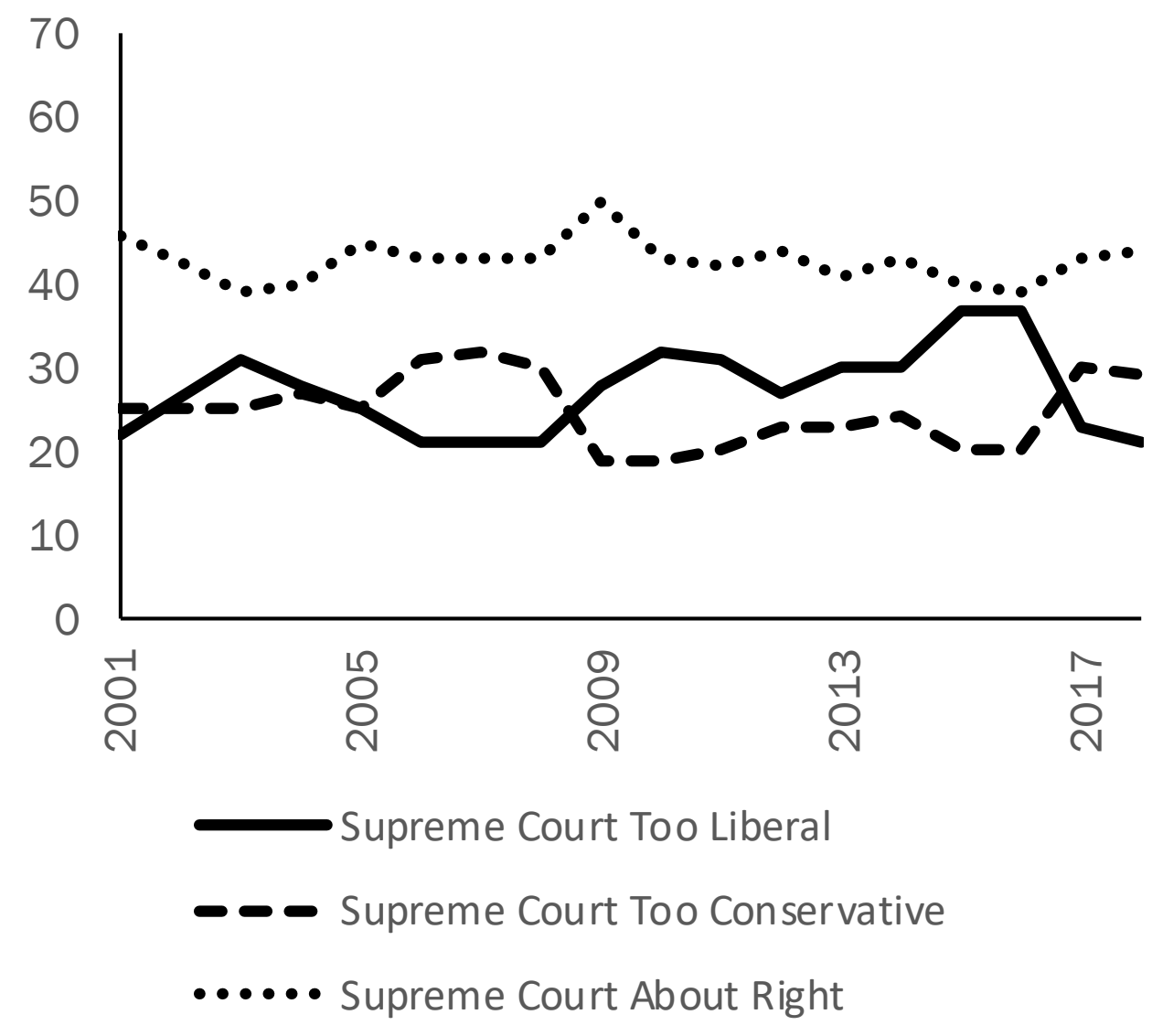

Figure 3: Annual Supreme Court is "Too Liberal, Too Conservative, or About Right" (Gallup), 2001-2018

observed between 1973 and 1993 from the respective means.

Gallup's “too liberal, too conservative, or just about right" question, though, allows individuals to provide information about whether the Court's decisions match their ideological preferences or whether its decisions deviate from their preferences in a particular direction. ${ }^{3}$ The percentage of Americans who say the Supreme Court is "about right" can be taken as an indicator of ideological convergence between the Supreme Court and the mass public, and this survey marginal multiplied by negative one is as our measure of ideological

\footnotetext{
${ }^{3}$ Gallup had only just begun asking this "too liberal, too conservative, or just about right?" question prior to the publication of Durr, Martin, and Wolbrecht's study. They simply did not have access to a time series of more direct evidence of the degree and direction of the ideological divergence between the Supreme Court and public opinion.
} 
divergence. ${ }^{4}$ Furthermore, the percentages saying the Court is "too liberal" and "too conservative," respectively indicate perceptions of the overall directional divergence between the ideological tenor of Supreme Court decisions and individuals' preferred level of policy liberalism. As before, we exclude "don't know" and "unsure" responses and rely on the percentages of respondents answering "too liberal," "too conservative," or "about right" among those who provide a definite response to the question to indicate the concepts of interest.

The third asks respondents, "Do you approve or disapprove of the way Congress is handling its job?" Once again, we exclude "don't know" and "unsure" responses and extract the percentage of respondents who say they approve of Congress among those who say they either approve or disapprove of Congress. This measures Americans' specific support for Congress (Durr and Wolbrecht, 1997; Ramirez, 2008, 2013; Rudolph, 2002).

The strength of these data is the very close correspondence between the substance of the questions asked by Gallup and the concepts of interest the theory of dynamic public support for the Supreme Court. Nearly two decades after Durr, Martin, and Wolbrecht's (2000) seminal study of the issue, the accumulation of these data provides the opportunity to reevaluate their claims with more direct evidence and to test extensions of those claims, such as those we propose here. The weakness of these data is their relatively modest coverage. These data are available from 2001 through 2018. Of course, this is a limited historical period, covering only the George W. Bush, Barack Obama, and early Donald Trump presidencies. These eighteen years of data provide relatively more leverage for evaluating theoretical claims about ideological divergence and public support for the Supreme Court, relatively less evidence for our claims about the role of presidential partisanship's influence on perception's of the Supreme Court since we very little quantitative basis for distinguishing the effects of presidential partisanship from the idiosyncrasies of individual presidents and the events that transpired during their times in office. We proceed with our analysis mindful of this limitation and of the need to reevaluate any conclusions we draw with

\footnotetext{
${ }^{4}$ Obviously, the sum of the percentages of respondents saying the Court is either "too liberal" or "too conservative" also indicates ideological divergence.
} 
additional data in the future.

\subsection{Estimation}

We first assess the presidential projection hypothesis by evaluating the association between presidential partisanship and perceptions of the ideological performance of the Supreme Court. Again, we expect that Americans see the Supreme Court in the political light cast by the president's partisanship. Therefore, more Americans will say the Supreme Court is "too liberal" when a Democrat is president rather than a Republican, and more Americans will say the Court is "too conservative" when the President is a Republican.

We use a difference of means tests and dynamic regression models to test the presidential projection hypothesis. In order to evaluate the association between presidential partisanship and perceptions of the Supreme Court's ideological performance, we perform a $t$ test for differences in the levels of "too liberal," "too conservative," and "about right" responses between periods with Republican and Democratic presidents (Table 1). Next, we estimate lagged dependent variable regressions of the percentages of "too liberal," "too conservative," and "about right" responses as a function of contemporaneous presidential partisanship (Table 2).

We then turn to our direct claims about specific support for the Supreme Court: the congressional support hypothesis, ideological divergence hypothesis, asymmetrical divergence hypothesis, and presidential partisanship hypothesis with a series of dynamic linear regression models. We begin by estimating a dynamic model of aggregate specific support for the Supreme Court as a function of perceived ideological deviation of the Court's decisions from the public's preferred level of liberalism in judicial policymaking and an indicator of congressional approval (Table 3). This allows us to test the ideological divergence and congressional support hypotheses supported by prior research.

Next, we extend this approach to test the asymmetrical divergence hypothesis and presidential partisanship hypothesis. We replace the measure of overall ideological divergence- 
the negative percentage of "about right" responses—for with indicators of directional ideological divergence between the Supreme Court and members of the mass public in a liberal direction and a conservative direction and add an indicator for presidential partisanship. Specifically, we estimate three ordinary least squares model of Supreme Court approval in a seemingly unrelated regression framework (Table 4).

\section{Results}

Tables 1 and 2 report the results of our tests of the presidential projection hypothesis. First, significantly greater percentages of Americans say the Supreme Court is too liberal when a Democrat is president than when a Republican is president, and significantly greater percentages of Americans say the Supreme Court is too conservative when a Republican is president than when a Democrat is president. During Democratic administrations, about a third of Americans (33.1\%), on average, judge the Supreme Court to be too liberal. When a Republican is president, only about a quarter of Americans (25.3\%) say the Court is too liberal. This represents an average difference of 7.1 percentages points, which is significantly different than zero. Similarly, During Democratic administrations, only $22.1 \%$ of Americans, on average, say the Supreme Court is too conservative compared to an average of $29.5 \%$ of Americans who say the Court is too conservative when a Republican is president. This difference (7.4) is also statistically significant. These differences are consistent with the presidential projection hypothesis.

Estimates of dynamic ordinary least squares models of the annual percentages of Gallup respondents saying the Supreme Court is either "too liberal" or "too conservative" provide additional evidence for the presidential projection hypothesis (Table 2). A Democratic president at time $t$ predicts that $6.5 \%$ more Americans will say the Supreme Court is too liberal than if a Republican were president, and a Democratic president predicts $7.4 \%$ fewer Americans the Supreme Court is too conservative than if a republican were president. 
Table 1: Presidential Partisanship and Mean Ideological Evaluations of the Supreme Court's Performance, 2001-2018

\begin{tabular}{lcccc} 
& \multicolumn{3}{c}{ Presidential Partisanship } & \\
& Democrat & Republican & Difference & $p$ \\
\hline & & & & \\
Too Liberal & 33.1 & 25.3 & $7.8^{*}$ & $p<0.01$ \\
Too Conservative & 22.1 & 29.5 & $-7.4^{*}$ & $p<0.01$
\end{tabular}

Note: The Democrat and Republican column entries are mean annual percentages of the indicated responses to Gallup's "too liberal, too conservative, or about right” question about the Supreme Court's performance described in the text for years each party control the presidency. ${ }^{*} p<0.05$; One-tailed tests.

Both of these estimates are statistically significant.

Table 3 reports the results of tests of the ideological divergence hypothesis and the congressional support hypothesis. Again, these hypotheses, derived from prior research, predict that public support for the Supreme Court is positively related to, respectively, ideological congruence between the Supreme Court and the mass public and to the public's general orientation toward government evident in evaluations of Congress (e.g. Durr, Martin, and Wolbrecht 2000). The model estimates the annual percentage of Gallup respondents expressing approval for the Supreme Court are a function of the first lag of the approval series, the negative percentage of Gallup respondent's saying the Supreme Court is "about right" (rather than "too liberal or too conservative") at time $t$, and the annual percentage of Gallup respondents expressing approval for Congress.

First, the data support the ideological divergence hypothesis. Consistent with our expectations, there is a significant, negative association between the negative percentage of respondents saying the Court's decisions are "about right" and the percentage of respondents saying they approve of the job the Supreme Court is doing. Each percentage point increase in judgments that the Court's decisions are not about right predicts an decrease of 1.4 percentage points in the Supreme Court's approval rating. This predicted effect is significantly greater than zero. Substantively, as Americans increasingly judge the Supreme 
Table 2: Presidential Partisanship and Dynamics in Ideological Evaluations of the Supreme Court's Performance, 20012018

Predictor (Expected Sign) Too Liberal Too Conservative

Too Liberal ${ }_{t-1}(+) \quad 0.3$

$(0.2)$

Too Conservative $_{t-1}(+) \quad 0.1$

Democratic President $t_{t}(+,-)^{\dagger} \quad 6.5^{*} \quad-7.4^{*}$

(1.9) (1.5)

$\begin{array}{lll}\text { Constant } & 17.4 & 27.9\end{array}$

(5.2) (4.9)

$\begin{array}{lll}R^{2} & 0.6 & 0.7\end{array}$

$\sqrt{M S E} \quad 3.6 \quad 2.6$

Note: Cell entries are OLS coefficients with standard errors in parentheses. ${ }^{*} p<0.05$ for one-tailed tests where direction hypotheses are indicated, two-tailed tests otherwise. ${ }^{\dagger}$ The expected sign is positive for the too liberal series and negative for the too conservative series. $\mathrm{N}=17$. 
Table 3: Ideological Congruence, Congressional Approval, and Specific Support for the Supreme Court, 2001-2018

\begin{tabular}{lc} 
Predictor (Expected Sign) & Estimated Effects \\
\hline & $-1.4^{*}$ \\
Negative \% About Right ${ }_{t}$ & $(0.2)$ \\
& $0.3^{*}$ \\
& $(0.1)$ \\
Congressional Approval $_{t}$ & 0.1 \\
& $(0.1)$ \\
Supreme Court Approval & \\
& -19.7 \\
Constant & $(10.7)$ \\
& \\
$R^{2}$ & 0.9 \\
$\sqrt{M S E}$ & 2.4 \\
\hline
\end{tabular}

Note: Cell entries are OLS coefficients with standard errors in parentheses. ${ }^{*} p<0.05$ for one-tailed tests where direction hypotheses are indicated, two-tailed tests otherwise. $\mathrm{N}=17$.

Court's decisions to fall within the zone of acquiescence, they become increasingly likely to say they approve of the job the Supreme Court is doing.

The data additionally support the congressional support hypothesis. There is a significant and positive association between congressional job approval and specific support for the Supreme Court. Each percentage point increase in congressional approval predicts a 0.3 percentage point increase in Supreme Court approval. This indicates that Americans views of the Supreme Court are tied to their evaluations of the federal government as a whole. When they view the government in general more favorably, they are apt to express more positive views of the Supreme Court, as well.

Next, we test the asymmetrical response hypothesis and the presidential partisanship hypothesis. The asymmetrical response hypothesis predicts specific support for the Supreme Court is more strongly negatively related to perceptions that the Court is overly liberal than 
perceptions that the Court is overly conservative. The presidential partisanship hypothesis predicts specific support for the Supreme Court is lower during a Democratic presidency than a Republican presidency.

We test these expectation by estimating three models of specific support for the Supreme Court together in a seemingly unrelated regression system. The dependent variable in each model is the percentage of respondents saying they approve of the Supreme Court in each survey year. Each model also includes as predictors the first lag of the dependent variable, contemporaneous congressional approval, an indicator or indicators of the public's ideological evaluations of the Supreme Court's decisions in year $t$, and an dummy variable indicating a sitting Democratic president.

These models are all variations of the model reported in Table 3 . That baseline model represented the public's ideological evaluations of the Supreme Court's decisions with the percentage of respondents saying the Supreme Court's decisions are "about right." In contrast, the model presented in the first column of results in Table 4 includes as a predictor the percentage of respondents saying the Court is "too liberal" (Model 1). The model reported in the second column of results includes as a predictor the percentage of respondents saying the Court is "too conservative" (Model 2). The model reported in the third column of results includes as predictors both the "too liberal" and "too conservative" series (Model 3). Also, again, each model includes a predictor indicating a Democratic president.

First, the data indicate support for the asymmetrical response hypothesis. In model 1, the data show a significant, negative association between aggregate perceptions the Supreme Court is too liberal and overall evaluations of the Supreme Court's job performance. Each percentage point increase in perceptions the Supreme Court is too liberal predicts a decrease of 0.7 percentage points in Supreme Court approval. Additionally, model 1's overall fit compares reasonably well to the baseline model. The model accounts for about $70 \%$ of the observed variance in the Supreme Court approval time series and has a root mean squared error of 2.9. The baseline model has an $R^{2}$ of 0.9 and a root mean squared er- 
Table 4: Ideological Congruence, Congressional Approval, and Specific Support for the Supreme Court, 2001-2018

\begin{tabular}{|c|c|c|c|}
\hline Predictor (Expected Sign) & Model 1 & Model 2 & Model 3 \\
\hline$\%$ Too Liberal $_{t}(-)$ & $\begin{array}{l}-0.7^{*} \\
(0.2)\end{array}$ & & $\begin{array}{l}-1.0^{*} \\
(0.2)\end{array}$ \\
\hline$\%$ Too Conservative $t_{t}(-)$ & & $\begin{array}{c}0.7 \\
(0.5)\end{array}$ & $\begin{array}{l}-0.6^{*} \\
(0.2)\end{array}$ \\
\hline Democratic President $_{t}(-)$ & $\begin{array}{c}5.5 \\
(5.2)\end{array}$ & $\begin{array}{c}5.0 \\
(2.2)\end{array}$ & $\begin{array}{c}2.7 \\
(2.4)\end{array}$ \\
\hline$\%$ Congressional Approval ${ }_{t}(+)$ & $\begin{array}{l}0.4^{*} \\
(0.2)\end{array}$ & $\begin{array}{l}0.4^{*} \\
(0.1)\end{array}$ & $\begin{array}{l}0.3^{*} \\
(0.1)\end{array}$ \\
\hline$\%$ Supreme Court Approval ${ }_{t-1}(+)$ & $\begin{array}{c}0.2 \\
(0.2)\end{array}$ & $\begin{array}{c}0.1 \\
(0.1)\end{array}$ & $\begin{array}{c}0.1 \\
(0.1)\end{array}$ \\
\hline Constant & $\begin{array}{c}13.9 \\
(18.4)\end{array}$ & $\begin{array}{c}55.3^{*} \\
(8.3)\end{array}$ & $\begin{array}{c}83.65 \\
(11.65)\end{array}$ \\
\hline $\begin{array}{l}R^{2} \\
\sqrt{M S E}\end{array}$ & $\begin{array}{l}0.7 \\
2.9\end{array}$ & $\begin{array}{l}0.5 \\
4.1\end{array}$ & $\begin{array}{l}0.8 \\
2.3\end{array}$ \\
\hline
\end{tabular}

Note: Cell entries are seemingly unrelated regression coefficients with standard errors in parentheses. ${ }^{*} p<0.05$ for one-tailed tests where direction hypotheses are indicated, two-tailed tests otherwise. $\mathrm{N}=17$. 
ror of 2.4. Despite providing no information about the residual division of public sentiment between "too conservative" and "about right" responses, the "too liberal" time series provides substantial predictive information about the state of specific support for the Supreme Court.

In contrast, estimates for model 2 show that the predicted effects of the "too conservative" series for Supreme Court approval are incorrectly signed and statistically indistinguishable from zero. Moreover, model 2 fits the Supreme Court approval time series substantially less well than model 1 . Model 2 accounts for only about half of the variance in the Court's approval, and its mean squared error is 4.1, about 40\% larger than model 1's mean squared error and about $80 \%$ larger than the baseline model's mean squared error. The scale of left-leaning disaffection from the Supreme Court's decisions alone, indicated by the "too conservative" time series, provides little predictive information about the level of public support for the Supreme Court.

The third model reported in Table 4 includes predicted effects for both the "too liberal" and "too conservative" time series. Model three indicates significant, negative associations between both directional indicators of ideological disaffection and public approval of the Supreme Court. The model predicts that each percentage point increase in perceptions that the Supreme Court is too liberal predicts a 1.0 percentage point decline in Supreme Court approval. Each percentage point increase in respondents saying the Supreme Court is "too conservative," though, predicts a decrease of only 0.6 percentage point in the Court's approval. The difference between these two coefficient estimates in statistically significant ( $p<0.02$; one-tailed test). Also, model 3's overall fit compares favorably to the baseline model; it's $R^{2}$ is 0.8 compared to the baseline's 0.9 , and it's root mean squared error is 2.3 compared to the baseline's 2.4 .

Together, these results show that there is ideological asymmetry in Americans' specific support Supreme Court. Aggregate judgments about the Supreme Court's performance as an institution are more strongly related to perceptions that the Court's decisions collectively deviate to the left-judgments that the Court is too liberal-than to perceptions that the 
Court deviates to the right-judgments that the Court is too conservative. This suggests that Americans on the political right, including conservative ideologues and Republican partisans, more readily translate changing evaluations of the ideological tenor of the Court's decisions into approval or disapproval of the the Court itself than Americans on the political left, progressive ideologues and Democratic partisans.

In addition to these result, the models also test the presidential partisanship hypothesis. The data provide little support for our expectation that presidential partisanship directly affects views of the Supreme Court's job performance. In each model, the estimated effect of a Democrat sitting as president is incorrectly signed and would be statistically distinguishable from zero in a two-tailed test only in Model 2, which suffers from a poor accounting for the public's ideological evaluations of the Supreme Court's performance. We therefore conclude that the effect of presidential partisanship for Supreme Court approval is fully mediated by the association between the president's party and ideological evaluations of the Supreme Court's performance.

Finally, we note that that all three models reported in Table 4 indicate support for the congressional approval hypothesis. There is a significant, positive association between approval of the Supreme Court and approval of Congress evident in each of these models. These estimates provide further evidence of the robustness of the association between evaluations of the Supreme Court and orientations toward the federal government as a whole embodied in Congress.

\section{Discussion and Conclusions}

First, our reading of recent developments in the literature on judicial power in the American separation of powers system (and in similarly structured presidential systems elsewhere) makes it clear that specific support for the Supreme Court is an important factor in the development and maintenance of judicial independence. All else equal, specific support 
for the Court creates electoral disincentives for members of Congress and the president to attempt to undermine federal judicial authority and promotes compliance with judicial decisions. Efforts to develop theoretical and empirical models of the public's approval of the Supreme Court_-and related concepts such as confidence-are essential for understanding national judicial politics and should be objects of ongoing scholarly attention.

Second, we find new evidence for the most prominent prior claims about the dynamics of specific support for the Supreme Court (e.g. Durr, Martin, and Wolbrecht 2000). Using data from the Gallup organization the directly queries respondents' ideological evaluations of the Court's decisions, we find evidence that Supreme Court approval is positively related to ideological congruence between the Court and the public. We also find additional evidence that Supreme Court approval is positively related to and overall positivity toward the federal government embodied by Congress.

Additionally, Gallup's data on Supreme Court approval and ideological evaluations of the Court's performance indicate significant support for this asymmetrical response hypothesis. Specific support for the Supreme Court is more strongly negatively related to perceptions that the Court is overly liberal than perceptions that the Court is overly conservative. This result is consistent with prior research on the value structure of individual ideological commitments and the nature of partisan coalitions in the United States.

We also show that political context plays a part in shaping the public's views of the Supreme Court. We theorize that presidential partisanship influences both the behavior of the Supreme Court and individuals' subjective perceptions of the Court's behavior. Our data provide little support for our expectation of a direct relationship between specific support for the Supreme Court and the president's party, but we find some evidence for our presidential projection hypothesis. Although the Gallup data cover only two completed presidencies, they are consistent with our expectation that a greater proportion of Americans say the Supreme Court is too liberal when a Democrat is president than when a Republican is president, and a greater proportion of Americans say the Supreme Court is too conservative 
when a Republican is president than when a Democrat is president. The small number of presidencies included in our data, though, lead us to regard this conclusion especially tentatively.

Together, the dynamics in Supreme Court approval that we identify have several implications. First they provide a reasonable framework for understanding the decline in approval for the Supreme Court over the last two decades and its modest increase since 2017. Our data suggest that the long decline in specific support is attributable to two factors. The first is an overall decline in approval of the federal government, including Congress. The last two decades have witness tremendous overall disaffection from national government, especially in Americans' views of Congress. Virtually no matter how the Supreme Court decides cases or conducts its business, Americans' alienation from government as an enterprise negatively colors their views of the judiciary. The Supreme Court is in some sense guilty by association.

The second is the growing perception that the Supreme Court was excessively liberal during the eight years of the Obama administration. Whatever the origins of this viewactual changes in patterns of the Court's behavior, salient liberal decisions, the appointment of progressive justices, or symbolic associations-Americans increasingly judged the Court to be excessively liberal during the Obama administration. Between 2008 and 2016, the percentage of Americans who told Gallup that the Supreme Court was "too liberal" rose from $21 \%$ to $37 \%$. In the same period, the percentage saying the Court was "about right" fell from $50 \%$ to $39 \%$ while the percentage saying the Court was "too conservative" stayed flat at around $20 \%$. These figures show nearly a decade of growing ideological disaffection from the Supreme Court's decisions in the direction most damaging to the public's overall levels of specific support for the Court.

The dynamics we identify also account for the uptick in Supreme Court approval evident in the Gallup data from the last two years. Since President Trump took office in 2017, as our presidential project hypothesis predicts, perceptions that the Court is overly liberal 
have declined sharply. Meanwhile, perceptions that the Court is about right or too conservative have spiked upward. Overall, Americans express greater ideological congruence with the Court and the balance of disaffect now sits among Americans on the political left who are less prone to translate their ideological disputes with the Court into their evaluations of the Court's institutional performance.

Our results also provide some insight into the seemingly asymmetrical partisan politics of Supreme Court nominations and confirmations (e.g. McElwee, 2018). For decades, Supreme Court nominations have seemingly loomed larger in Republican politics than Democratic politics. This was starkly evident in the 2016 presidential election cycle. Republican primary candidates extensively discussed potential Supreme Court nominees including candidate Trump's publication of a short list of nominees vetted by conservative activities. At the same time, Democratic candidates gave the issue relatively little attention despite the Republican-controlled Senate's historic refusal to consider President Obama's nomination of Merrick Garland to fill the Supreme Court vacancy create by Justice Scalia's passing.

This pattern was similarly observable in the politics of Brett Kavanaugh's nomination to the Supreme Court. Although Americans' attitudes about then-Judge Kavanaugh's nomination reflected substantial partisan divisions from the outset Jones (2018), the nomination was not especially salient among Democratic voters until allegations of sexual misconduct by Kavanaugh became public (Wolf, 2018a,b). Prior to media reports of Christine Blasey Ford, Deborah Ramirez, and others' accusations of Kavanaugh's sexual assault and other sexual misconduct, Kavanaugh's nomination seemed assured and elite Democrats' efforts to motivate voters on the Supreme Court issue had gained little traction. A political strategist quoted anonymously in Politico explicitly noted the parallels between failed efforts to motivate Democratic and liberal voters around judicial nominations in the 2016 election and similar pre-accusation campaigns against Kavanaugh's nomination, "I'm old enough to remember when Merrick Garland would be a rallying cry for Hillary supporters"(Cadelago, 2018). After the sexual assault claims against Kavanaugh were revealed, of course, Demo- 
cratic and liberal opposition to Kavanaugh's became much more intense. However, arguments against Kavanaugh's confirmation largely focused on his conduct and temperament rather than the legal and policy implications of his pivotal place on the Supreme Court (Farrow and Mayer, 2018). In contrast, Republicans and conservatives continued to support Kavanaugh despite the allegations against him because of his legal and political views (Review, 2018).

The politics the Garland and Kavanaugh nominations are both consistent with popular notions of asymmetries in the Republican and Democratic parties' investment in national judicial politics. The data suggest that these differences are not illusory. Rather, there are systematic differences in the ways that Americans on the political right and Americans on the political left interact with the judiciary. Finally, our results also take a novel step in empirically demonstrating a salient political consequences from the zone of acquiescence theorized by Stimson (1999). Our work shows that the direction of ideological divergence between a set of policy outcomes and the public's medially preferred courses of action can be consequential for the public's aggregate evaluations of a governing institution. It is feasible that similar asymmetries may be evident in the dynamics of other performance evaluation series, such as presidential approval, and other dimensions of macro-level public sentiment, such as policy mood and macro partisanship. Additional research on these problems may yield valuable new insights into the dynamic properties of American national politics. 


\section{References}

Ansolabehere, Stephen D., and Ariel White. 2018. "Policy, Politics, and Public Attitudes Toward the Supreme Court." American Politics Research DOI: 10.1177/1532673X18765189: $1-25$.

Armaly, Miles T. 2016. Reassessing Public Confidence in the Supreme Court. San Juan, Puerto Rico: .

Bailey, Michael A., Brian Kamoie, and Forrest Maltzman. 2005. "Signals from the Tenth Justice: The Political Role of the Solicitor General in Supreme Court Decision Making.” American Journal of Political Science 49(1): 72-85.

Brenan, Megan. 2017. "Supreme Court Approval Highest Since 2009." https://news.gallup.com/poll/237269/supreme-court-approval-highest-2009.aspx.

Cadelago, Christopher. 2018. "Why Trump Won't See a Kavanaugh bump.” POLITICO (September): https://politi.co/2Q3UknL.

Caldeira, Gregory A. 1986. "Neither the Purse nor the Sword: Dynamics of Public Confidence in the Supreme Court." American Political Science Review 80(4): 1209-1226.

Caldeira, Gregory A. 1987. "Public Opinion and The U.S. Supreme Court: FDR's CourtPacking Plan.” American Political Science Review 81(December): 1139-1153.

Caldeira, Gregory A. 1991. “Courts and Public Opinion.” In The American Courts: A Critical Assessment, ed. John B. Gates, and Charles A. Johnson. Washington, D.C.: CQ Press pp. 303-334.

Caplan, Lincoln. 1987. The Tenth Justice: the Solicitor General and the Rule of Law. New York, NY: Vintage Books.

Center, Pew Research. 2015. "Negative Views of Supreme Court at Record High, Driven by Republican Dissatisfaction.” (July): 17. 
Chappell, Henry W., Thomas M. Havrilesky, and Rob Roy McGregor. 1993. "Partisan Monetary Policies: Presidential Influence Through the Power of Appointment." The Quarterly Journal of Economics 108(Feb): 185-218.

Clark, Tom S. 2009. “The Separation of Powers, Court Curbing, and Judicial Legitimacy." American Journal of Political Science 53(4): 971-989.

Converse, Philip E. 1964. "The Nature of Belief Systems in Mass Publics." In Ideology and Discontent, ed. David E. Apter. New York: Free Press pp. 206-262.

Converse, Philip E., Aage R. Clausen, and Warren E. Miller. 1965. "ElectoralMyth and Reality: The 1964 Election.” American Political Science Review 59: 321-334.

Dahl, Robert. 1957. "Decision-Making in a Democracy: The Supreme Court as a National Policy-Maker.” Journal of Public Law 6(Fall): 279-295.

Durr, Robert H. 1993. "What Moves Policy Sentiment?” The American Political Science Review 87(March): 158-170.

Durr, Robert H., James B. Gilmour, and Christina Wolbrecht. 1997. "Explaining Congressional Approval.” American Journal of Political Science 41(1): 175-207.

Easton, David. 1965. A Systems Analysis of Political Life. New York: Wiley.

Edwards, George C. 1976. "Presidential Influence in the House: Presidential Prestige as a Source of Presidential Power.” American Political Science Review 70(Mar): 101-113.

Edwards, George C. 1980. Presidential Influence in Congress. New York: W. H. Freeman.

Ellis, Christopher R., and James A Stimson. 2012. Ideology in America. New York: Cambridge University Press.

Enns, Peter K., and Patrick C. Wohlfarth. 2017. Making Sense of the Supreme Court-Public Opinion Relationship. Routledge Handbooks Online. 
Erikson, Robert S., Michael B. MacKuen, and James A. Stimson. 2002. The Macro Polity. Cambridge, UK: Cambridge University Press.

Farrow, Ronan, and Jane Mayer. 2018. "A Sexual-Misconduct Allegation Against the Supreme Court Nominee Brett Kavanaugh Stirs Tension Among Democrats in Congress.” The New Yorker (September).

Feldman, Stanley, and John Zaller. 1992. "The Political Culture of Ambivalence: Ideological Responses to the Welfare State." American Journal of Political Science 36(February): 268307.

Franklin, Charles H., and John E. Jackson. 1983. “The Dynamics of Party Identification.” The American Political Science Review 77(December): 957-973.

Friedman, Barry. 2009. The Will of the People: How Public Opinion Has Influenced the Supreme Court and Shaped the Meaning of the Consitution. New York, NY: Farrar Straus and Giroux.

Funston, Richard. 1975. “The Supreme Court and Critical Elections.” American Political Science Review 27: 327-358.

Gibson, James L. 2012. Electing Judges: The Surprising Effects of Campaigning on Judicial Legitimacy. University of Chicago Press.

Gibson, James L., and Gregory A. Caldeira. 2009. Citizens, Courts, and Confirmations: Positivity Theory and the Judgments of the American People. Princeton University Press.

Gibson, James L., and Michael J. Nelson. 2014. "The Legitimacy of the US Supreme Court: Conventional Wisdoms and Recent Challenges Thereto." Annual Review of Law and Social Science 10(1): 201-219.

Gibson, James L., and Michael Nelson. 2018. Black and Blue: How African Americans Judge the U.S. Legal System. New York: Oxford University Press. 
Gibson, James L., Gregory A. Caldeira, and Lester Kenyatta Spence. 2003a. "Measuring Attitudes Toward the United States Supreme Court.” American Journal of Political Science 47(2): 354-367.

Gibson, James L., Gregory A. Caldeira, and Lester Kenyatta Spence. 2003b. "The Supreme Court and the US Presidential Election of 2000: Wounds, Self-Inflicted or Otherwise?" British Journal of Political Science 33(04): 535-556.

Goggin, Stephen N., and Alexander G. Theodoridis. 2017. "Disputed Ownership: Parties, Issues, and Traits in the Minds of Voters." Political Behavior 39(Sep): 675-702.

Goggin, Stephen N., and Alexander G. Theodoridis. 2018. "Seeing Red (or Blue): How Party Identity Colors Political Cognition.” The Forum 16(1): 81-95.

Goren, Paul. 2001. "Core Principles and Policy Reasoning in Mass Publics: A Test of Two Theories." British Journal of Political Science 31(January): 159-177.

Grossman, Matt, and David A. Hopkins. 2016. Asymmetric Politics: Ideological Republicans and Group Interest Democrats. Oxford University Press.

Hall, Matthew E. K. 2011. The Nature of Supreme Court Power. New York: Cambridge University Press.

Hall, Matthew E. K., and Joseph Daniel Ura. 2015. "Judicial Majoritarianism." Journal of Politics Forthcoming.

Herbert McClosky, Paul J. Hoffmann, and Rosemary O'Hara. 1960. "Issue Conflict and Consensus Among Party Leaders and Followers." The American Political Science Review 54(2): 406-427.

Hetherington, Marc J. 1998. "The Political Relevance of Political Trust." American Political Science Review 92(December): 791-808. 
Hetherington, Marc J. 2005. Why Trust Matters: Declining Political Trust and the Demise of American Liberalism. Princeton University Press.

Hitt, Matthew P., and Kathleen Searles. 2018. "Media Coverage and Public Approval of the U.S. Supreme Court.” Political Communication 0(May): 1-21.

Jones, Jeffrey M. 2016. "U.S. Supreme Court Job Approval Rating Ties Record Low." https://news.gallup.com/poll/194057/supreme-court-job-approval-rating-ties-recordlow.aspx.

Jones, Jeffrey M. 2018. "Views of Kavanaugh Confirmation Remain Closely Divided.”.

Keele, Luke. 2007. "Social Capital and the Dynamics of Trust in Government." American Journal of Political Science 51(April): 241-254.

Kellstedt, Paul M., David A. M. Peterson, and Mark D. Ramirez. 2010. "The Macro Politics of a Gender Gap.” Public Opinion Quarterly 74(March): 477-498.

Kramer, Larry D. 2004. The People Themselves: Popular Constitutionalism and Judicial Review. New York, NY: Oxford University Press.

Kriner, Douglas L., and Andrew Reeves. 2015. "Presidential Particularism and Divide-theDollar Politics." American Political Science Review 109(1): 155-171.

Malhotra, Neil, and Stephen Jessee. 2014. "Ideological Proximity and Support for the Supreme Court." Political Behavior 36(December): 817-846.

McClosky, Herbert, and John R. Zaller. 1984. The American Ethos. Cambridge, MA: Harvard University Press.

McElwee, Sean. 2018. "Democrats Must Stop Pretending the Supreme Court Is Apolitical." (June). 
Merrill, Alison Higgins. 2018. The Dynamics of Issue Attention on the United States Supreme Court PhD thesis Texas A\&M University.

Merrill, Alison Higgins, Nicholas D. Conway, and Joseph Daniel Ura. 2017. "Confidence and Constraint: Public Opinion, Judicial Independence, and the Roberts Court." Washington University Journal of Law \& Policy 54: 209-228.

Mondak, Jeffery J., and Anke Grosskopf. 1998. "Do Attitudes Toward Specific Supreme Court Decisions Matter? The Impact of Webster and Texas v. Johnson on Public Confidence in the Supreme Court.” Political Research Quarterly 51(3): 633-654.

Mondak, Jeffrey J. 1992. "Institutional Legitimacy, Policy Legitimacy, and the Supreme Court.” American Politics Quarterly 20(4): 457-477.

Mondak, Jeffrey J., and Shannon Ishiyama Smithey. 1997. “The Dynamics of Public Support for the Supreme Court.” Journal of Politics. 59 (November): 1114-1142.

Nolan McCarty, Keith T. Poole, and Howard Rosenthal. 2008. Polarized America: The Dance of Ideology and Unequal Riches. Cambridge, MA: MIT Press.

Page, Benjamin I., and Robert Y. Shapiro. 1982. "Changes in Americans' Policy Preferences, 1935-1979.” Public Opinion Quarterly 46: 24-42.

Page, Benjamin I., and Robert Y. Shapiro. 2010. The Rational Public: Fifty Years of Trends in Americans’ Policy Preferences. Chicago, IL: University of Chicago Press.

Peake, Jeffrey S. 2001. "Presidential Agenda Setting in Foreign Policy." Political Research Quarterly 54(Mar): 69-86.

Perry, H. W. 1994. Deciding to Decide: Agenda Setting in the United States Supreme Court. Cambridge, MA: Harvard University Press.

Philip E. Converse, Aage R. Clausen, and Warren E. Miller. 1965. "Electoral Myth and Reality: The 1964 Election." American Political Science Review 59(2): 321-336. 
Ramirez, Mark D. 2008. "Procedural Perceptions and Support for the U.S. Supreme Court." Political Psychology 29(5): 675-698.

Ramirez, Mark D. 2013. “The Policy Origins of Congressional Approval." The Journal of Politics 75(January): 198-209.

Review, National. 2018. “Justice Prevailed.”.

Riker, William H. 1980. "Implications from the Disequilibrium of Majority Rule for the Study of Institutions." The American Political Science Review 74(June): 432-446.

Rudolph, Thomas J. 2002. "The Economic Sources of Congressional Approval.” Legislative Studies Quarterly 27(4): 577-599.

Segal, Jeffrey A., Chad Westerland, and Stefanie A. Lindquist. 2011. "Congress, the Supreme Court, and Judicial Review: Testing a Constitutional Separation of Powers Model.” American Journal of Political Science 55(January): 89-104.

Segal, Jeffrey A., Richard J. Timpone, and Robert M. Howard. 2000. "Buyer Beware? Presidential Success through Supreme Court Appointments.” Political Research Quarterly 53(Sep): 557-573.

Sinozich, Sofi. 2017. "Public Opinion on the US Supreme Court, 1973-2015." Public Opinion Quarterly 81(March): 173-195.

Stimson, James A. 1999. Public Opinion in America: Moods, Cycles, and Swings. 2nd ed. Boulder, CO: Westview Press.

Stimson, James A. 2004. Tides of Consent: How Public Opinion Shapes American Politics. New York, NY: Cambridge University Press.

Ura, Joseph Daniel. 2014. "Backlash and Legitimation: Macro Political Responses to Supreme Court Decisions." American Journal of Political Science 58(January): 110-126. 
Ura, Joseph Daniel, and Alison Higgins Merrill. 2017. "The Supreme Court and Public Opinion." The Oxford Handbook of U.S. Judicial Behavior (June).

Ura, Joseph Daniel, and Christopher R. Ellis. 2012. "Partisan Moods: Polarization and Party Preference Dynamics." Journal of Politics 74(1): 277-291.

Ura, Joseph Daniel, and Patrick C. Wohlfarth. 2010. "An Appeal to the People: Public Opinion and Congressional Support for the Supreme Court." Journal of Politics 72(4): 939-956.

Whittington, Keith E. 2005. “Interpose Your Friendly Hand': Political Support for the Exercise of Judicial Review by the United States Supreme Court." American Political Science Review 99(November): 583-596.

Wlezien, Christopher. 1995. "The Public as Thermostat: Dynamics of Preferences for Spending." American Journal of Political Science 39(November): 981-1000.

Wlezien, Christopher. 1996. "Dynamics of Representation: The Case of US Spending on Defence." British Journal of Political Science 26(01): 81-103.

Wolf, Richard. 2018a. "Brett Kavanaugh Vote: Republicans Block Democrats' Demands for Subpoenas, Set Date on Supreme Court Nominee.".

Wolf, Richard. 2018b. "Five Reasons Brett Kavanaugh's Nomination to the Supreme Court is Controversial.". 